\title{
The Effect of Different Improvement Methods on Growth of Pyrus Betulaefolia Grown on Alkali-saline Land
}

\author{
Wuque Gong ${ }^{1}$, Jinghui Yang ${ }^{1}$, Yanjun Qin ${ }^{1}$, Weizi \\ Huang ${ }^{1}$, Yanjun Liu ${ }^{1}$, \\ ${ }^{1}$ The College of Horticulture and Landscape,Tianjin \\ Agricultural University,Tianjin,300384,China
}

\author{
Chao Zhang ${ }^{2}$ \\ ${ }^{2}$ College of Environmental Science, University of \\ Tsukuba in Japan, Tokyo,Japan
}

\begin{abstract}
In order to explore practical and efficient method of improvement to alkali-saline land in Binhai area of Tianjin. Four kinds of improvement method were used with plants of Pyrus Betulaefolia which grew on the heavy alkali-saline land and combining biological and physical ways in Tianjin.The different improvement methods were compared in alkali-saline land and according to plant height, ground diameter of stem, new shoot length, the thickness of tree crown and leaf curtain. The results showed that Economic Type, Long Term Type, Rapid type, Ecological Type was better than $\mathrm{CK}$ in all improvement methods. The stem of plants grew thicker and higher by Rapid type and Long Term Type than others. The new shoot length and thickness of tree crown and leaf curtain was maximum by Rapid type. New shoot length, plant height, ground diameter of stem and crown breadth was in abundance by Ecological type except Rapid type(in the second level). The plants grew best by Rapid type and Long Term Type according to all the growth indicators.
\end{abstract}

Keywords- biological method, physical method, Economic type, Long Term type, Rapid type, Ecological type.

\section{INTRODUCTION}

Soil salinization is a worldwide problem. According to The incomplete statistics of United Nations Scientific and Cultural Organization and The Food and Agriculture Organization, the saline-alkali land area was about 9.54 million $\mathrm{hm} 2$ around the world. In our country, it was about 0.99 million $\mathrm{hm}^{2[1]}$ and was widely distributed in China. China is one of the countries with lands of most serious salinity, especially in the coastal area, such as in Tianjin, which had brought significant threat to agricultural production ${ }^{[2-6]}$.

As a result, many experts thought the alkali-saline land was the urgent problem which need to be solved in agricultural development and environmental management ${ }^{[7]}$. There were many ways to improved alkali-saline land in our country such as biological, physical and chemical ways ${ }^{[8]}$. But every method has its drawbacks. In order to find out practical and efficient method, four kinds of method were used with biological and physical ways in alkali-saline land of Tianjin.

Pyrus Betulaefolia belongs to the Rosaceae and is woody tree. It was native to northern, northeast and central provinces of China, it was not only used for pear rootstock but also it was used for ornamental plant in the North heavy saline-alkali land. Because of its strong resistance and good growth in partial acid and alkaline soil, it could endure about $0.5 \%$ salinity in soil ${ }^{[9]}$. At the same time, it is resistant from water logging, may grow well in cohesive soil air with poor permeability. Therefore, Pyrus Betulaefolia was chosen for the experiment. In order to provide a reference for the improvement of saline-alkali land, different method improvement was studied.

\section{DISCUSSED PROBLEMS}

The experiment land was located in Forestry Bureau Saline-alkali Land Improvement Center of Dagang district in Tianjin. Dagang district is located in the south of Tianjin with flat land and average elevation of $3 \mathrm{~m}$ and temperate semi-humid continental monsoon climate of the northern hemisphere. There are many rivers in the area, but most of them was with less water and lower water level now than before. The salinity in shallow groundwater is high, the chloride content is high too in the water. The soil is $0.4 \% \sim 1 \%$ salt content and poor air permeability.

There were 5 kinds of planting hole in the saline-alkali soil improvement experiment, CK, Economic type, Long Term type, Rapid type, Ecological type. Each row was a treatment, every treatment had 5 plants (a total of 40 strains per treatment ) and 8 repetitions.

Added two rows of contrast around the experiment land, the planting density was $3 \times 4 \mathrm{~m}$, the hole's size of length $\mathrm{X}$ width $\mathrm{X}$ high $=1 \mathrm{X} 1 \mathrm{X} 1(\mathrm{~m} 3)$.

In planting pit, $\mathrm{CK}$ was $50 \mathrm{~kg} /$ pit organic fertilizer and garden soil, Economic type was salt layer insulation on bottom of pit, $50 \mathrm{~kg} /$ pit organic fertilizer and garden soil, as shown in figure 2. Long Term type was salt layer insulation on bottom of pit, $50 \mathrm{~kg} /$ pit organic fertilizer and improved microbial preparation (EM mother liquid of ecological probiot, diluted 200 times) and garden soil, as shown in figure 3. Rapid type was salt layer insulation on bottom of pit, $50 \mathrm{~kg} / \mathrm{pit}$ organic fertilizer and $50 \mathrm{~kg} / \mathrm{pit}$ sand and garden soil shown in figure 4, Ecological type was salt layer insulation on bottom of pit, $50 \mathrm{~kg} / \mathrm{pit}$ organic fertilizer, 6/pit ventilation tube (sand pillar) and garden soil in which the sand pillar was $10 \mathrm{~cm}$ long, $1 \mathrm{~m}$ diameter, as shown in figure 5 .

The 2 years old plants of Pyrus Betulaefolia were planted in the middle of march in 2013. The plants were watered 5 times and sprayed 3 times and fertilized 2 times a year according to local routine management. The plant's 
height, ground diameter of stem, new shoot length, the thickness of tree crown and leaf curtain was measured in October of 2014. The thickness of tree crown (V) was $\mathrm{V}=$ $\pi \mathrm{D} 2 / 8 \times \mathrm{L}$.

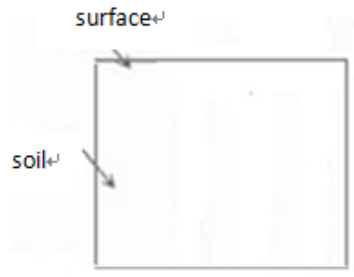

Figure $1 \mathrm{CK}$

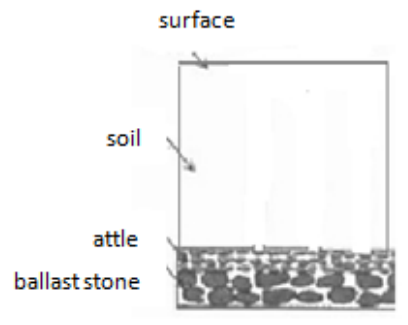

Figure 2 Economic type

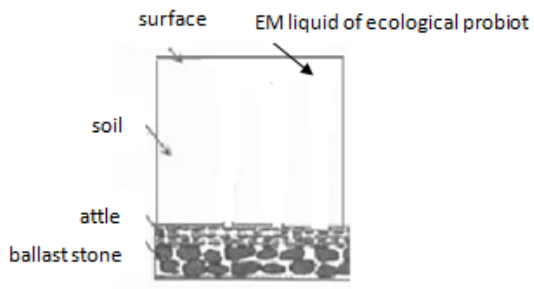

Figure 3 Long Term type

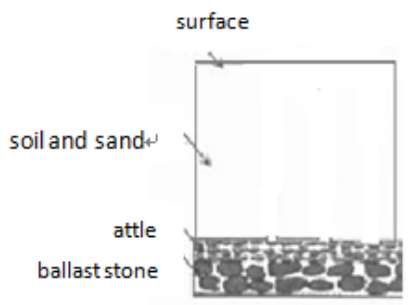

Figure 4 Rapid type

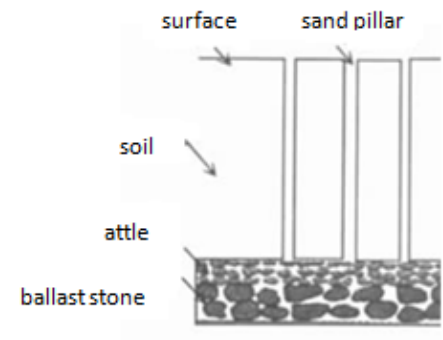

Figure 5 Ecological type

\section{RESULTS AND ANALYSIS}

A. The effect of different improvement methods on plant height and ground stem diameter of Pyrus Betulaefolia grown on alkali-saline land

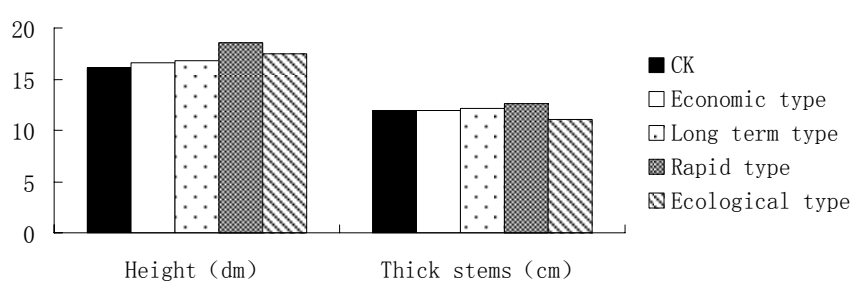

Figure 6 The effect of different improvement methods on plant height and ground stem diameter of Pyrus Betulaefolia grown on alkali-saline land

Plant's height was $18.50 \mathrm{dm}$, ground stem diameter was $12.6 \mathrm{~cm}$, the numerical values by Rapid type were the highest in all treatments (figure 6). The plant's height by Ecological type was $17.43 \mathrm{dm}$, but ground stem diameter was only $11.1 \mathrm{~cm}$ which was the lowest in all treatment. The plant's height by Long Term type was $16.81 \mathrm{dm}$, in the third of all treatment. Their ground stem diameter was $12.1 \mathrm{~cm}$ ranked second. The plant's height by Economic type was $16.63 \mathrm{dm}$, ranked fourth, ground stem diameter was $11.9 \mathrm{~cm}$, in the third of all. The plant's height of CK was $16.08 \mathrm{dm}$, numerical value was the lowest in all treatments, ground stem diameter was $11.9 \mathrm{~cm}$, and as the same as Economic type. According to plant's height, the sequence was: Rapid type $>$ Ecological type $>$ Long Term type $>$ Economic type $>$ CK. According to ground stem diameter, the sequence was: Rapid type $>$ Long Term type $>$ Economic type $=\mathrm{CK}>$ Ecological type. In a word, plant height and thick stems was obviously better in pits of Rapid type treatment than the others. So, the method of Rapid type was the best and was associated with the local salt soil.

The method of mixing sand into the saline-alkali soil was greater than other type significantly from the above two growth indicators. The sands were mixed in pits of Rapid type treatment, which could improve the soil permeability and make the plants grew well.

$B$. The effect of different improvement methods on new shoot length of Pyrus Betulaefolia grown on alkalisaline land

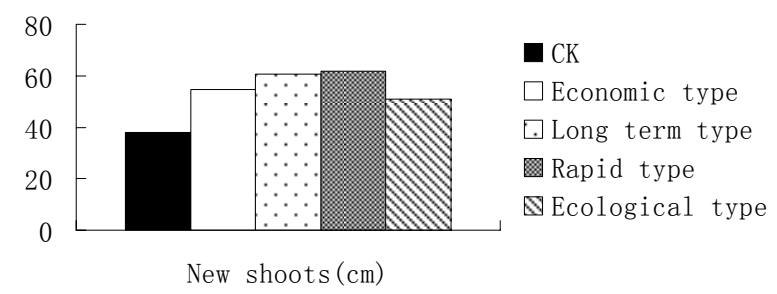

Figure 7 The effect of different improvement methods on new shoot length of Pyrus Betulaefolia grown on alkali-saline land 
The new shoots of plants were $61.95 \mathrm{~cm}$ long in pits of Rapid type, the longest in all treatment (figure 7), secondly were in Long Term type and it was $60.53 \mathrm{~cm}$ long, the next was in Economic type, new shoots was $54.66 \mathrm{~cm}$ long. And then were in Ecological type, which was $51 \mathrm{~cm}$ long. The last was CK which was only $37.79 \mathrm{~cm}$ long. It showed that different mode of improvement in alkali-saline land made difference in new shoot growth of Pyrus Betulaefolia. The sequence was Rapid type $>$ Long Term type $>$ Economic type $>$ Ecological type $>$ CK. The Rapid type was the best way in all treatments according to new shoots growth and the result was same as $A$.. Ecological type was the worst way than others, but still better than CK.

The treatment result of Ecological type may be related to the drought in spring since the sand pillars had drained off too much water which was necessary for plant growth, especially in the early growth of plant and vigorous growth period of shoots which is watered sensitive time. So, the branch growth was inhibited significantly and led to the lower new shoots in Ecological type treatment.

In addition, plants survival rate of Ecological type treatment was the lowest grown in early spring (the data was not shown here).

C. The effect of different improvement methods on the thickness of tree crown and leaf curtain of Pyrus Betulaefolia grown on alkali-saline land

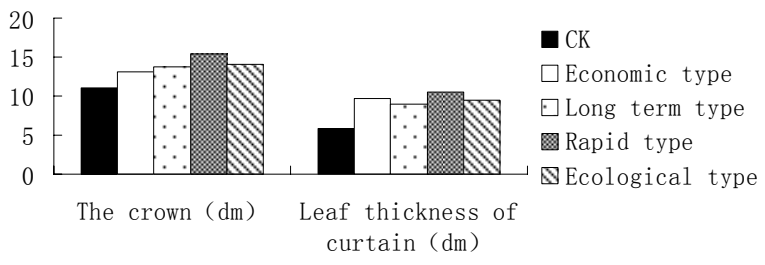

Figure 8 The effect of different improvement methods on the thickness of tree crown and leaf curtain of Pyrus Betulaefolia grown on alkalisaline land

In figure 8 , the change between thickness of tree crown and leaf curtain had the same trend. But, the effect of different mode of improvement in alkali-saline land was different in the change of thickness of tree crown and leaf curtain. The thickness in pits of Rapid type was $15.43 \mathrm{dm}$ which was best of all. Second was in Ecological type which was $14.07 \mathrm{dm}$. Third was in Long Term type which was $13.75 \mathrm{dm}$. Fourth was in Economic type which was $13.13 \mathrm{dm}$. The last was CK which was only $11.08 \mathrm{dm}$. The sequence was: Rapid type $>$ Ecological type $>$ Long Term type $>$ Economic type $>$ CK.

As thickness of leaf curtain, the best was Rapid type which was $10.5 \mathrm{dm}$ thick. Second was Economic type which was $9.73 \mathrm{dm}$ thick. Third was Ecological type which was $9.43 \mathrm{dm}$. Fourth was Long Term type which was $9.00 \mathrm{dm}$. The last was CK which was $5.83 \mathrm{dm}$. The sequence was Rapid type $>$ Economic type $>$ Ecological type $>$ Long Term type $>$ CK. The Rapid type treatment were the best way in all and the result was as the same as $A$. and $B$.

\section{Comprehensive analysis}

Comprehensive analysis of growth index in Pyrus Betulaefolia under the five kinds of improvement modes in saline-alkali soil

TABLE 1 COMPREHENSIVE ANALYSIS OF GROWTH INDEX IN PYRUS BETULAEFOLIA UNDER THE FIVE KINDS OF IMPROVEMENT MODES IN SALINE-ALKALI SOIL

\begin{tabular}{|c|c|c|c|c|c|}
\hline \multirow[b]{2}{*}{$\begin{array}{l}\text { Improvement } \\
\text { modes }\end{array}$} & \multicolumn{5}{|c|}{ Growth Index } \\
\hline & $\begin{array}{l}\text { Plant } \\
\text { height }\end{array}$ & $\begin{array}{l}\text { Ground } \\
\text { diameter } \\
\text { of stems }\end{array}$ & $\begin{array}{l}\text { Length } \\
\text { of New } \\
\text { shoots }\end{array}$ & $\begin{array}{l}\text { Thickness } \\
\text { of leaf } \\
\text { curtain }\end{array}$ & $\begin{array}{l}\text { Thickness } \\
\text { crown }\end{array}$ \\
\hline CK & 5 & 4 & 5 & 5 & 5 \\
\hline Economic type & 4 & 3 & 3 & 2 & 4 \\
\hline $\begin{array}{l}\text { Long Term } \\
\text { type }\end{array}$ & 3 & 2 & 2 & 4 & 3 \\
\hline Rapid type & 1 & 1 & 1 & 1 & 1 \\
\hline Ecological type & 2 & 5 & 4 & 3 & 2 \\
\hline
\end{tabular}

All the growth indexes of plants under Rapid type treatment were ranked in the first place within 5 kinds of improvement types. It showed the Rapid type was the best improvement way to Pyrus Betulaefolia. With the Long Term type, ground thickness of stems and new shoots of plants was ranked in the second, the plant's height and the tree crown was ranked in the third, the leaf curtain was ranked in the fourth. In the Economic type, thickness of leaf curtain was ranked in the second, the ground stems and the new shoots were ranked in the third and the height was ranked in the fourth. In the Ecological type, plant height and the crown was ranked in the second, the leaf curtain was ranked in the third, the new shoots was ranked in the fourth, the ground stems was ranked in the fifth. And in the CK, all growth indexes were ranked fifth except the ground stems ranked fourth.

\section{CONCLUSIONS}

In the aline-alkali soil improvement project, the 4 kinds of improvement types made plants of Pyrus Betulaefolia grew better than CK. And the Rapid type and Long Term type made the ground stems added the thicker and the plants grew higher. In the Rapid type treatment, the new shoots and tree crown and the leaf curtain were all the best. In the Ecological type, its growth indexes were in the second level. Therefore, according to the growth of Pyrus Betulaefolia, it should be that Rapid type was the best way, and then were Long Term and Ecological type, next was Economic type and the last was CK.

\section{ACKNOWLEDGEMENTS}

We offer our thanks to National Agricultural Science and Technology Achievements Transformation Fund (Grant Number: 2012GB2A100015) and Major scientific and technological projects in Tianjin Science and Technology Commission (Grant Number: 
12ZCDZNC0480 and 14JCTPJC00530) in the People's Republic of China.

\section{REFERENCES}

[1] Zaituniguli Kuerban. Effect of Saline Soil on the Yield and Sugar Contents of Sweet Sorghum[A]. Xinjiang Academy of Agricultural Sciences, 2011,48 (7):1244-1248.

[2] Zhang Lu, Sun Xiangyang, Shang Chenghai. Review and Prospect of Improvement Present Situation on Coastal Saline-alkali Area in Tianjin[J]. Chinese Agricultural Science Bulletin,2012,26(18):180185.

[3] Zhou Heping, Zhang Lixin, Yu Feng. Review and Prospect of Improvement of Saline-alkali Area in China[J]. Anhui Agriculture,2007,(11):159-164.

[4] Wu Qingshu, Guo Yunfeng, Dou Lianbin. Tianjin saline-alkali improvement ideas[J]. Agro-environment and Development,2004,(2):32-33.

[5] Zhang Jianfeng. Saline Soil Amelioration and Forestation Techniques. Journal of Northeast Forestry University,2002,30(6):124-129.

[6] Ma Chen, Ma Lvyi, Liu Taixiang. Research Progress on Saline Land Improvement Technology[A]. World Forestry Research,2012,02:25-28.

[7] Qin Pei. Focuses on the Coastal Wetland's Ecosystem Research. Wetland Science and Management,2006,01.

[8] Zhang Jianfeng, Zhang Xudong. World Resources of Saline Soil and Main Amelioration Measures[J]. Research of Soil and Water Conservation,2005,12(6) 28-30,107

[9] Wang Haiying, Sun Jianshe, Wang Xujing. The recent study progress on salt tolerance of fruit trees. Journal Of Agricultural University Of Hebei,2000,2:28-30 